\title{
Artigo
}

\section{London walling: Brexit and the securitisation of migration in the United Kingdom}

Muro de Londres: Brexit e a securitização da migração no Reino Unido

Orion Siufi Noda ${ }^{1}$

DOI: $10.5752 /$ P.1809-6182.2017v15.n1.p13

Recebido em: 08 de novembro de 2017 Aprovado em: 04 de julho de 2018

\begin{abstract}
This article aims to analyse the link between Brexit and the securitisation of migration in the United Kingdom. Through Securitisation Theory and Critical Discourse Analysis, the chief argument is that migration was successfully securitised, serving as a tool to the pro-Brexit campaigns.
\end{abstract}

Key-words: Securitisation, Brexit, Migration

\section{Resumo}

Este artigo visa analisar a conexão entre o Brexit e a securitização de migraçóes no Reino Unido. Por meio da Teoria de Securitização e Análise Critica de Discurso, o argumento principal é o de que a migração foi securitizada com êxito, servindo como uma ferramenta às campanhas pró-Brexit.

Palavras-chave: Securitização, Brexit, Migração

1. Doutorando em Relaçôes Internacionais no Instituto de Relaçôes Internacionais da Universidade de São Paulo. mestrado em Segurança Internacional pela Rijksuniversiteit Groningen (2017). Pesquisador na area de Relaçôes Internacionais com ênfase em Segurança Internacional e Processos de Securitização . ORCID: 0000-0003-3705-2296 


\section{Introduction}

In June 2016, the world turned its attention to a referendum that took place in the United Kingdom (UK). The British population was summoned to the voting booths to voice their opinion on the UK's permanence in the European Union (EU). The outcome, in favour of the UK's withdrawal, triggered a lot of speculation regarding not only the future of the EU, but also that of the UK.

Apart from the questions concerning the new political setting of Europe, the result of the referendum had other important impacts. The results of the vote, commonly referred to as "Brexit", also led a plethora of scholars to analyse what were the core causes of the population's will to leave the EU. This issue is supplementary to the raging debate between "eurosceptics" and "eurofederalists" in the matters of the EU project, that is, those who argue that the European countries would be better off without a supranational organisation, and those who disagree, with beliefs that a joint and united Europe is stronger (MORGAN, 2005).

One of the main arguments used in order to advocate for Brexit was related to the migratory issues in Europe. The argument had its foundations in the promotion of the UK's control of its own borders in order to thwart immigration - which was seen as a hazard for the development and prosperity of the UK. This paper aims to analyse the discourse propagated by the campaigns in favour of leaving the EU and its advocates in order to assess whether a securitisation of migration in the UK was indeed successful.

It is evident that the propaganda from the campaigns backing the UK's retreat from the EU portray immigrants and the migratory flow towards the UK as a hindrance for development, arguing that these factors supersaturate public welfare programs, however, what is to be investigated in this paper is whether this issue was successfully securitised or not. In other words, the objective is to evaluate whether the speech act of securitisation, which created an extraordinary order with the purpose of mitigating the threat, was triumphant.

To achieve its goals, the paper will rely on both primary and secondary sources. Literature on the theoretical concepts to be used will be analysed, especially regarding those of securitisation theory within the Copenhagen School of Security, and discourse analysis techniques. As the aim of the paper is to ascertain whether the discourse utilised by the Brexit advocates contained elements of securitisation, the paper will be guided by a leading research question which can be formulated in the following terms: has migration been successfully securitised by the pro-campaigns in the case of Brexit?

The paper will be structured in the following manner: first, a section will be dedicated to the literature review of the theoretical framework to be applied on the paper. This section will present the securitisation theory within the Copenhagen School of Security, how it works and the elements of securitisation to be later sought in the case study. Additionally, as this paper concerns discourse analysis, the elements of this approach will also be further explored.

Having laid out the theoretical framework, an analysis of the case study will ensue. Through Critical Discourse Analysis, the campaigns in favour of Brexit will be investigated in order to verify whether the elements of securitisation of migration in the UK were successful or not. Last, but not least, conclusions drawn from said analysis will be presented in the last section of this paper. This homonymous chapter will also explore the implications of said conclusions, exploring the importance and significance of the findings to the academic field.

The next section will encompass the theoretical framework to be applied on the case study. It 
will be in charge of the definition of not only the key-concepts, such as "securitisation" and "speech act" - in order to provide a better understanding of not only the theory, but of the paper as a whole but also of what are the criteria for success in case of the securitisation move.

\section{Securitisation Theory}

The Copenhagen School of Security, in contrast to the more traditional schools of thought on Security, adopts a wider concept of the field, as Buzan et al. (1998, p. 23) put it: "Security' is the move that takes politics beyond the established rules of the game and frames the issue either as a special kind of politics or as above politics." To classify a referent object as being a security issue is to categorise it as fundamental and under threat, a threat that poses risks to the object's own existence. It is viable to expand topics of security beyond the political-military threshold, making it possible to include any issue that might present a threat to the referent object's own existence - be it in the social, political, military, economic or environmental arenas. Therefore, Queiroz (2012) argues that:

The established criterion to define a specific topic as being a security issue is an intersubjective social construction that is directly related to the discursive emphasis attributed to the substantial political effects of a given threat to the referent object (QUEIROZ, 2012, p. 577, own translation ${ }^{2}$ )

From this broader approach of security, the Copenhagen School of Security developed its greatest contribution for Security Studies: the securitisation theory. According to Buzan et al. (1998), the phenomenon of securitisation consists of the

2. "Os critérios estabelecidos para definir determinado tema como sendo de segurança é uma construção social intersubjetiva e está diretamente relacionado à ênfase discursiva atribuída aos possíveis efeitos políticos substanciais de uma dada ameaça existencial a um objeto referente." process of elevating a given topic from the "regular politics" arena to an extraordinary political setting, one that, due to its own characteristics, legitimises drastic measures

The process of securitisation relies on two main variables: the securitising move executed by the securitising actor through the characterisation of a referent object as threatened, and the acceptance by the target audience of said securitising speech. The securitising process is structured in three distinct phases: 1) the existential threat; 2) the emergency course of action; and 3) the effects the violation of the "regular politics" rules has on the relations between the units of the International System (Buzan et al., 1998). To understand the securitisation process, it is necessary to better define these concepts.

Firstly, the securitising actor is the one who utters the speech that securitises a given topic. From this actor originates the initiative not only to demonstrate that the referent object is threatened, but also the articulation to convince the audience. In the contemporary world, it is observable that the elites - especially those involved with State-running activities - are the main and most frequent securitising actors: "In naming a certain development a security problem, the 'State' can claim a special right, one that will, in the final instance, always be defined by the state and its elites." (WÆVER, 2007, p. 75).

The referent object is the object presented as existentially threatened through speech act. It is to whom or what the speech refers to in order to imply a threat against its survival. The nature of the referent object varies and it can originate from a plethora of areas, but in general, the referent object refers to the State itself. Therefore, the discursive qualification of the threats aimed at the State, its sovereignty, and its existence as a political entity can be seen as a securitisation process (BUZAN $e t$ al., 1998; BUZAN; WÆVER, 2003). 
In that sense, Buzan et al. (1998) mention three facilitating conditions for a successful securitising speech act:

(1) the demand internal to the speech act of following the grammar of security, (2) the social conditions regarding the position of authority for the securitizing actor - that is, the relationship between speaker and audience and thereby the likelihood of the audience accepting the claims made in a securitizing attempt, and (3) features of the alleged threats that either facilitate or impede securitization (BUZAN et al., 1998, p. 33).

From the internal conditions, the construction of a discursive narrative that qualifies any referent object as existentially threatened is the paramount condition. Framing the threat and conditions as an existential threat to the referent object is crucial for a successful securitising process. Regarding the second condition, it is possible to infer that the elites are generally the actors who play the role of the securitising actor, since they are legitimised in institutional roles (W/EVER, 2007). Finally, concerning the last external condition, there are features of the alleged threat that might facilitate or thwart the securitising process. According to Buzan et al., "It is more likely that one can conjure a security threat if certain objects can be referred to that are generally held to be threatening - be they tanks, hostile sentiments, or polluted waters." (BUZAN et al., 1998, p. 3). Therefore, it is possible to say that these potentially threatened referent objects were not considered a security issue by themselves, but were rather transformed into it by historical reasons. Nevertheless, the Copenhagen School of Security remains unclear on the criteria of a successful securitisation move. Therefore, the criteria will be established in an ad-hoc basis, in order to adequately fit the case. To assess the rate of success of the securitisation of migration in the UK, three criteria has been chosen, based both on the general concepts of the securitisation theory, and the specificity of the case: 1) the presence of all the elements of securitisation - the securitising actor, the threat, the referent object, and the audience; 2) the sanctioning of an extraordinary measure - in this case, Brexit itself; and 3) popular support.. Apart from the core concepts of securitisation theory, another theoretical framework has to be further explored in order to achieve this paper's goals. To verify the presence (or lack thereof) of securitising elements, the discourse will have to be analysed; for that, a theory of discourse analysis will be employed.

\section{Critical discourse analysis}

Discourse analysis has a wide range of branches, but all share the basic assumption that "our ways of talking do not neutrally reflect our world, identities and social relations, but rather play an active role in creating and changing them" (JØRGENSEN AND PHILIPS, 2002, p. 1). For the scope of this paper, the focus will be on Critical Discourse Analysis.

Critical Discourse Analysis differentiates itself from the other branches of discourse analysis theories since its focus lies on the link between the discourse itself and social and cultural developments in various domains. In this sense, Critical Discourse Analysis is makes for the ideal methodological tool supplementary to Securitisation Theory: the first is used as a method to identify the alleged threats embedded in the discourse presented by the securitising actor. In critically analysing the discourse, the goal is to lift the bias present in these securitising discourses.

Norman Fairclough (1995), a pioneer of Critical Discourse Analysis, proposes five bedrock assumptions that define this theory branch: 1) the character of social and cultural processes is partially linguistic-discursive; 2) discourse is both consti- 
tutive and constituted; 3) language use should be empirically analysed within its social context; 4) discourse functions ideologically; and 5) Critical Discourse Analysis is politically committed to social change.

In that regard, it is noticeable that discourse (not seen only as speeches, but also text and visual language) has a dialectic relation with the world and context in which it is uttered or displayed; it does more than simply reflect the ideologies behind the author - in other words, constitute a reality -, but it is also constitutive, meaning it is affected by it. Also key for the understanding of Critical Discourse Analysis is the fact that every form of communication is not politically neutral, it is loaded with a meaning and ideology which is committed to social change (FAIRCLOUGH, 1995; LOCKE, 2004; WODAK AND CHILTON, 2005; VAN DIJK, 2008; FAIRCLOUGH AND FAIRCLOU$\mathrm{GH}, 2012)$.

Another important factor is the context in which a discourse is present. Akin to Austin's (1962) ideas, it makes all the difference a situation in which a set of words is uttered or displayed. As an example, Austin (1962) mentions the particular situation of marriage. When the bride in the altar says "I do", her discourse has a completely different meaning and significance if those words were said in a disparate context, even though it is a reply to an inquiry. Additionally, the discourse in the example mentioned is not only a statement of truth or lie, but a part of the act itself, being committed to social change and loaded with a predetermined ideology (AUSTIN, 1962; FAIRCLOUGH, 1995).

In sum, it is noticeable that any form of discourse - be it a public speech, an advertisement, an image on a website or, adapting to modern times, a social media post - is not free from any political or ideological bias. Language is used as an instrument to influence, sway opinion and is, as Fairclough
(1995) noted, committed to social change, but one that is akin to the actor's beliefs; in other words, there is no such thing as an innocent discourse.

Having presented the theoretical framework of this article, the next section will carry out an analysis of the case at hand - Brexit - relying on the theoretical framework built in order to verify whether securitisation of migration occurred in that context.

\section{Securitising migration in the UK}

In 2016, the British population had the opportunity to voice their opinion and vote on the future of the UK in regards to its permanence in the EU. There were several campaigns, both in favour of the UK's withdrawal as well as against it. The arguments for both campaigns varied in its origins and development, but mostly centred in economic development, security and social programs (which, in a way, unite the first two areas). Even though the support for Brexit came from a variety of sectors of the British society, they were mainly backed by the official campaigns for Brexit, whose discourse will be in focus here, more specifically, the "Leave" and the "Vote Leave, Take Control" campaigns.

The origins of the arguments pro-Brexit are various, but they focus mostly on economic factors - particularly the weekly contribution of the UK to the EU - and border security issues. Immigration is a variable that touches both arenas, as it is extensively mentioned in their discourse. The main argument here is that as long as the UK remains in the EU, even though it is not part of the Schengen zone - which allows a free flow of people within the countries that integrate it -, the amount of migrants coming from the EU and settling in the UK is out of British control. In June $8^{\text {th }}$, for instance, Michael Gove and Dominic Raab from the 
"Vote Leave, Take Control" campaign gave speech emphasizing the numbers of migrations to the UK and its dangers:

Last year, over a million arrived in Europe from the Middle East, north Africa and beyond. They swept across the continent. In the UK, net migration was 333,000 last year. The government's pledge is to reduce it to the tens of thousands. Yet, net migration from the EU was 184,000 alone [...] It's no good dismissing concerns based on people's real life experiences, of finding their local schools full, of struggling to get a GP appointment, or a home they can afford, of having their wages undercut. (GOVE; RAAB, 2016).

According to the campaigns' discourses, this "uncontrollable" flow of migration not only poses a security threat to the UK, as a large number of people are allowed in, but also has its toll on the UK's welfare programs. As an example, the campaign's websites make use of simply elaborated visual language in the form of images that frames the alleged impact of immigration in the economic and societal factors, which is visible in the Figures 1 and 2 below, extracted from the "Vote Leave, Take Control" campaign (2017):
UK Prime-Minister Theresa May - in charge of leading the dissociation of the country from the EU - has stated time and time again that "Brexit means Brexit" (MAY, 2016, min. 1:12). May showed no signs of an attempt to bar the Brexit process, even noting that the UK's withdrawal from the EU could not coexist with the former integrating the single-market setting currently shared by the EU's member States due to the UK's unwillingness to abide by the rules that regulate the $\mathrm{EU}$ single-market (May, 2016).

By employing Critical Discourse Analysis, it is possible to notice a few of the factors highlighted by Fairclough (1995) regarding the usage of visual artefacts for particular reasons within the campaigns' discourse. For instance, it is clear that the discourse present in these images suggest a given preconceived ideology. If analysed within the context, that is, the purpose of the discourse (Brexit), it is also noticeable that it is a biased use of language and it is committed to a social change - the withdrawal of the UK from the EU. However, as Hansen (2011) argues, visual representations alone cannot objectively express an idea; it has to be employed in conjunction with a rather specific voca-

Figure 1- The EU exponsion.

\section{The EU is expanding}

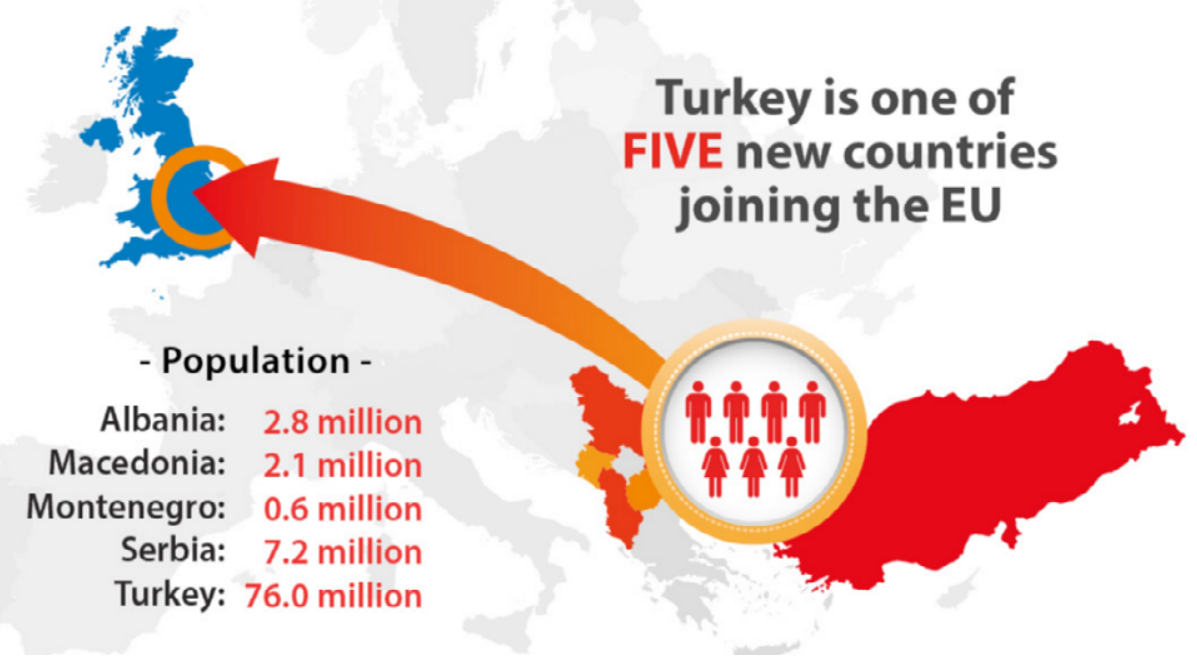

Source: "Vote Leave, Take Control”, 2017. 


\section{Immigration will continue to be out of control}

\author{
Nearly 2 million people came to the \\ UK from the EU over the last ten \\ years. Imagine what it will be like in \\ future decades when new, poorer \\ countries join.
}

Source: "Vote Leave, Take Control”, 2017.

bulary to be able to "speak Security". In this aspect, it can be what Buzan et al. (1998, p.33) referred to as a "grammar of security".

In Figure 2, by stating "Imagine what it will be like in the future decades when new, poorer countries join", the discourse attempts to drastically sway the reader's opinion by using a pejorative tone, inviting the reader to speculate on the disaster that will follow when "poorer countries" join. In that sense, it considers that "poorer countries" automatically means the UK having to increase its monetary contribution to the EU, as well as potentially having an even larger inflow of migrants without a thorough security check. The image selected to accompany this carefully crafted linguistic statement further deteriorates the image of migration by portraying what it seems to be a highly securitised camp, protected by barbed wire, and people - dressed in a specific set of clothing attire - attempting to escape, an analogy to prison breaks, comparing the possible immigrants to prisoners

The discourse of the campaigns that pushed for Brexit heavily relied on immigration as a negative factor that not only poses this security threat, but also thwarts the economic development of the UK. Through discourse, the advocates of Brexit managed to demonise immigration and immigrants in the UK and to establish a connection between that and a po- tential higher growth rate in economy, welfare and infrastructure. As shown in Figure 3, the campaigns associate the UK's contribution to the EU to potential uses of the same amount of capital.

It is, therefore, inferred that by leaving the EU, the UK would indeed use the capital previously destined to the EU to materialise the weekly construction of National Health Service (NHS) hospitals in a "tit-for-tat" manner. The reality, however, might not match the expectations; due to the fact that Brexit is an extremely new topic whose consequences are yet to unfold, it is impossible to pinpoint if this swap of EU contributions for NHS Hospitals will hold true.

Merging this analysis of the Brexit campaigns' discourse with the theoretical framework of securitisation, it is possible to delineate a correlation between the two. The discourse presented by the campaigns in favour of Brexit had in their rhetoric the appointment of a scapegoat, a "common enemy" that would be responsible for the alleged impedance of the UK's development. In that sense, amidst the refugee crisis in Europe, the campaigners found their "enemy of the State" in migration.

The way in which the Brexit campaigns frame migration - as a security and economic threat that has gotten out of hand - is an attempt to elevate the topic to an extraordinary political arena in 
Figure 3- The economic costs of remoining in the EU.

\section{The EU will cost us more and more}

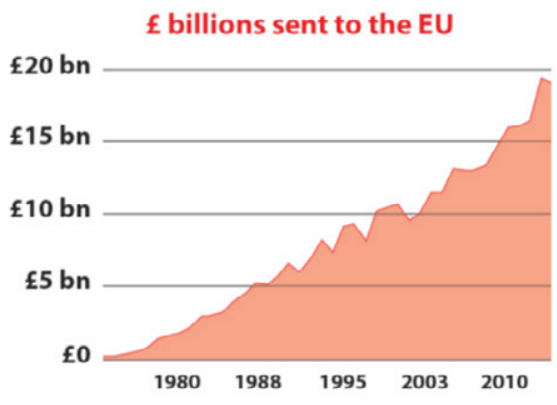

Source: "Vote Leave, Take Control", 2017.

which equally extraordinary measures to attenuate the situation posed against the UK are expected to be sanctioned (or not tampered with, at least). By attempting to create this scenario of emergency, the solution conveniently presented by the securitising actors (the campaigners for Brexit, commonly referred to as "Brexiters") would be the withdrawal of the UK from the EU itself. In other words, Brexit would be the measure to overhaul the supposed threat of migration that loomed large over the UK and restore order in the British political setting. In that sense, it is already possible to delineate the criteria established to evaluate the successfulness of the securitising move.

All of the key-elements that integrate the securitisation theory are indeed present in the case at hand. The securitising actor (the Brexiters) were highly influential figures with authority to utter the speech act to an audience (the British population) in order to protect a referent object (the UK and its development and survival) from a threat (immigration).

As for the second and third criteria established to determine a successful securitisation, the referendum had a positive outcome for Brexit, which would not have been possible had it not had support from the population. In this context, the outcome of the referendum implies that it had popular support, since the target audience was the British

\section{The EU already costs us} $£ 350$ million a week

- enough to build a new NHS

hospital every week. We get less

than half of this back, and have no

say over how it's spent.

population itself, and Brexit was the extraordinary and emergency measure sanctioned (thus, supported) by the population.

The positive results of the referendum might indicate that the securitisation of migration did in fact have an impact on the population's opinion, though it must be stated that proof of a direct correlation and impact is virtually impossible without a nation-wide poll with specific questions regarding the impact of the Brexiters' securitising move. Sectors of the British population actually believe that migration (even of highly-skilled individuals) is harmful to the UK's development, a fact that is closely related to the anti-migration propaganda used by the Brexit campaigns. In this sense, it is possible to ascertain that the ideologically biased discourse of the Brexiters was committed to a particular social change and indeed managed to acquire the support or consent of the target audience - the British population - regarding extraordinary measures that perhaps would not be accepted otherwise. The framing of migration as a problem managed to shape large portions of the British public opinion concerning the issue, which in turn served its purpose to sanction an extraordinary measure, presented as the viable option to save the UK.

Therefore, in agreement to the securitisation theory assumption that securitisation is a speech 
act (BUZAN et al., 1998; WÆVER, 2003) and to the criteria chosen, elements of a successful securitisation move can be identified within the discourse utilised by the campaigns in favour of Brexit. Adjusting the topic to the theoretical framework laid out in previous sections, the referent object that must be protected is the State itself - in this case, the UK -, but more specifically, the State's development and well-being, measured in economic and security standards. The issue that poses a threat to the referent object is, as framed by the Brexiter's discourse, migration, but whether that is in fact a threat or not is unimportant for the discourse's effectiveness - since it is committed to a particular social change, the role of the discourse is solely to convince the target audience of the existence of said threat.

Nevertheless, it must be firmly stated that Securitisation Theory is not one without flaws. The fluidity of the theoretical framework postulated by Buzan et al. allows for a large margin of subjectivity and openness to interpretation of the several particles of the method of securitisation. To this end, there is 1) no clear criteria to determine whether the securitising move was successful; 2) no clear criteria to determine whether the results achieved by the emergency measures were a direct impact of the securitising move - despite having established that direct relation of the implementation of the measures and the securitising move; and 3) no single way to determine which element falls into which category (referent object, threat, measure etc).

Still, the dialectic relationship that the discourse shares with Brexit itself is translated into an autopoietic social system, following Niklas Luhmann's (2013) system theory, between the process of securitisation of migration and public opinion. An autopoietic relationship indicates a self-feeding loop of information and communication that confirms and reinforces itself, similarly what happens to the securitisation of migration and public opinion: by portraying migration as an issue, the discourse shapes the target audience's opinion, strengthening the argument of the discourse itself, which in turn manages to reach an even larger audience and so on.

The nature of this relation, as Luhmann (2013) argues, allows little to no room for new input. In the case at hand, this is bound to be harmful to the unfolding of the events after Brexit. The creation of this loop would entail an increasing xenophobic feeling etched in the British identity for no reason other than the repetition and thoughtless acceptance of a speech.

\section{Final considerations}

This paper has set out the task of investigating and analysing the discourse utilised by the campaigns in favour of Brexit in order to ascertain whether elements of a successful securitisation process regarding migration to the UK could be identified. In that sense it is possible to state that the securitisation of migration was indeed successful as it fulfils the three criteria established and ultimately helped to mould the British public opinion in favour of the withdrawal of the UK from the EU.

Subject to the framework of the Critical Discourse Analysis theory developed by Fairclough (1995), the Brexiters' campaigns are indeed ideologically biased and committed to a particular and predestined social change. It comes as no surprise that the bias is towards Brexit, but upon closer inspection, it is noticeable the framing of migration as one of the main reasons to support the UK's exit from the EU. Two of the main governance areas, namely economy and security, are argued to be closely related and negatively affected by immigration. According to the Brexiters' rhetoric, immigration represented a threat not only to the UK's, but also a heavy economic burden; permanence in the EU would only serve to enlarge this security threat and 
aggravate the UK's economic burden. This framing of migration as a threat to the UK creates an extraordinary political setting in which extraordinary measures are allowed and sanctioned by a particular audience. In the context of Brexit, this measure would be Brexit itself, an ultimate measure sanctioned by the British population in order to save the UK, allowing for the possibility of stating that the securitising move may have indeed played a key role in the withdrawal of the UK from the EU.

Nevertheless, due to the dialectic relationship between the Brexiter discourse and public opinion, taking into account their autopoietic relationship, it is feasible that the "hostility" created towards immigration and migrants in the UK due to the securitising move only grows. Though it is impossible to ascertain whether migration was only securitised to sway the vote's outcome or even if migration is indeed a threat, it is likely that the effects of the securitisation process are etched in the British population's rhetoric. The impact of these events and how long it will last, however, remains to be seen.

\section{References}

AUSTIN, J. How to Do Things with Words, London: Oxford University Press, 1962.

BUZAN, B.; HANSEN, L. The Evolution of International Security Studies, Cambridge: Cambridge University Press, 2009. BUZAN, B.; WÆVER, O. Regions and Powers: the Structure of International Security, Cambridge: Cambridge University Press, 2003.

BUZAN, B., WÆVER, O., and de Wilde, J. Security: a New Framework for Analysis, Boulder: Lynne Rienner Publishers, 1998.

FAIRClOUGH, I.; FAIRCLOUGH, N. Political Discourse Analysis: A Method for Advanced Students, New York: Routledge, 2012.

FAIRCLOUGH, N. Critical Discourse Analysis: the Critical Study of Language, London: Longman, 1995.

HANSEN, L. Theorizing the image for Security Studies: Visual securitization and the Muhammad Cartoon Crisis. European Journal of International Relations, Volume 17, n. 1, 2011, pp. 51-74.
JØRGENSEN, M.; PHILIPS, L. Discourse Analysis: as Theory and Method, London: Sage, 2002.

LOCKE, T. Critical Discourse Analysis, London: Continuum, 2004.

LUHMANN, N. Introduction to Systems Theory, Cambridge: Polity Press,2013.

MAY, T. Address to Birmingham supporters, 2016. Available in<http://www.independent.co.uk/news/uk/politics/theresa-may-brexit-means-brexit-conservative-leadership-no-attempt-remain-inside-eu-leave-europe-a7130596.html> Access in : 19 jan. 2017

MORGAN, G. Political Theory and European Integration, Princeton: Princeton University Press, 2005.

QUEIROZ, F. A Hidropolítica Platina no Contexto do Complexo Regional de Segurança da América do Sul: Entre o Conflito e a Cooperação 1960-1979. Contexto Internacional, v. 34, n. 2, 2012, p. 573-616.

VAN DIJK, T. Discourse and Context: a Sociocognitive Approach, Cambridge: Cambridge University Press, 2008.

WÆVER, O. Security, the Speech Act: Analysing the Politics of a Word. Tel Aviv: Copenhagen Centre for Peace and Conflict Research, 2003.

WÆVER, O. Securitization and Desecuritization. International Security, v.1, n. 3, 2007, p. 66-98.

WHY VOTE LEAVE, n.d. image. Avaiable in : <http://www. voteleavetakecontrol.org/why_vote_leave.html> Access in: 19 jan. 2017

WODAK, R. (Ed.); CHILTON, P. (Ed.). A New Agenda in (Critical) Discourse Analysis, Amsterdam: John Benjamins Publishing Group, 2005. 